\title{
Albert Einstein: religiosidade e política como valores do homem de ciência
}

\author{
Albert Einstein: religiosity and politics as values \\ of the man of science
}

\author{
Prof. Dr. Eduardo Simões \\ UFT \\ eduardosimoes@uft.edu.br

\section{ORCID} \\ http://orcid.org/0000-0001- \\ 7375-8574
}

Recebido em:19/06/2020

Aceito em:07/10/2021

\section{Resumo}

O objetivo do presente artigo é o de apresentar um Albert Einstein diferente daquele que comumente encontramos nos meios de comunicação social, bem como nos livros didáticos: a imagem de um gênio da Física, cujas produções teóricas deixaram marcas que muito dificilmente serão superadas e cujos efeitos práticos de suas teorias vemos a todo momento serem aplicados no campo da tecnologia. Gostaríamos, portanto, de apresentar, mesmo que de forma restrita, as facetas de um Einstein engajado nas causas mais nobres do seu tempo. Aquele que, enquanto homem de ciência, não se furtou de sua responsabilidade social e do alto de sua fama pronunciou-se sobre os mais diversos temas que afligiam o seu século. Especialmente, aqui, trataremos de dois posicionamentos de Einstein a respeito de temas que vimos ser cruciais em sua vida pessoal, a saber, "ciência e religião" e "ciência e política". Esperamos que as linhas que se seguem, possam servir de exemplo e estímulo àqueles que as lerem.

Palavras-chave: Einstein, religião, ciência, política.

\section{Abstract}

The aim of this article is to present an Albert Einstein different from the one we commonly find in the media, as well as in textbooks: the image of a genius of Physics, whose theoretical productions left marks that will hardly be overcome and whose practical effects of his theories we see at all times are applied in the field of technology. We would therefore like to present, even if in a restricted way, the facets of an Einstein engaged in the most noble causes of his time. He who, as a man of science, did not shy away from his social responsibility and from the height of his fame, spoke on the most diverse themes that afflicted his century. Especially, here, we will deal with two positions of Einstein regarding themes that we saw to be crucial in his personal life, namely, "science and religion" and "science and politics". We hope that the following lines can serve as an example and encouragement to those who read them.

Keywords: Einstein, religion, science, politics. 


\section{Introdução}

Conhecido como uma das mentes mais brilhantes da história da ciência, Albert Einstein (1879-1955) efetivamente deixou o seu nome cravado na história da humanidade. Suas grandes produções em Física Teórica abrangem os trabalhos sobre a Relatividade Geral e Restrita, o movimento browniano, o efeito fotoelétrico, a ideia de fóton, a equivalência massa-energia, a estatística de Bose-Einstein e o paradoxo EPR, que constituiu uma "pedra no sapato" para a Interpretação de Copenhague da mecânica quântica. Não foi sem propósito que, em 1999, Einstein foi classificado pela revista Time, entre as pessoas mais importantes e influentes de sua época, como "a pessoa do século XX". Suas contribuições para o mundo da Física Teórica são muito grandes, contudo, foram suas contribuições pela causa da paz e da liberdade entre os homens que o colocaram no panteão das personalidades mais veneráveis que por aqui passaram. Sabemos que o que restou de sua imagem entre o público mais amplo, até pela influência da educação científica das nações, foi a imagem do gênio, da mente brilhante que conseguia enxergar a realidade de um ponto de vista que ninguém mais conseguia, cujas teorias, até hoje, vêm sendo comprovadas e empregadas à medida do nosso desenvolvimento científico-tecnológico. Entretanto, pouco sabemos do Einstein político e pacifista, que lutava contra o fascismo e contra o nacional-socialismo; que mantinha suas convicções e crenças de matriz judaica, mas que não abdicava da noção de religiosidade cósmica; que tinha uma forte inclinação pela ideia da criação de um governo mundial; que não negligenciava as questões sociais - a exemplo da questão dos negros e das minorias - e que não abria mão da reflexão sobre a relação entre ciência e vida. Sobre esses temas, Einstein proferiu diversas palestras, redigiu dezenas de cartas, escreveu diversos artigos, assinou uma série de manifestos. Por se tratar de uma luta inglória em campos em que a derrocada dos grandes titãs (capitalistas, comunistas, nacionalistas, etc.) era incerta, ainda assim, Einstein não abandonou a luta, e muito do que hoje somos enquanto sociedade que vivencia uma certa estabilidade bélica, certamente, deve-se aos seus esforços pela paz em um momento tenso da história da humanidade. Quem lê e acompanha a sua história sente as dores de sua luta, acompanha e vivencia sua solidão, experimenta a profundidade de muitas das suas decepções, sofre com os ataques por ele tolerado, decepciona-se com o terreno infértil onde ele semeava suas ideias de paz e toma parte de um ceticismo que muitas das vezes parece insistir em lhe acompanhar, mas que, ainda assim, não o faz perder as esperanças de que dias melhores virão. Suas ações apontam para o que estava por trás do seu ideário, a saber, a luta pelo direito de que o mundo possa continuar existindo. Por detrás dos ideais sócio-político de Einstein, certificamos haver duas motivações que lhe são principais, mas que não são exclusivas: I) a da crença na inescrutável concepção de que não há lugar para o acaso no Universo, isto é, "Deus não joga dados" (... ob der liebe Gott würfelt). Sendo assim, a causalidade, a determinação, a certeza, subjazem ao realismo universal e conecta tudo a todos. Isso acaba por abrir espaço no seu pensamento para uma concepção de "religiosidade cósmica" de fundo spinoziano. II) a da firme convicção do papel social do cientista ou do sábio, conforme ele gostava de dizer, nesse mundo onde as forças políticas exercem forte influência sobre as massas "sem nenhum escrúpulo e sem qualquer senso de responsabilidade" (EINSTEIN, 1981, p. 65). Dessa forma, Einstein inaugura uma prática que, infelizmente, praticamente se dissolve no período pós-einsteiniano: a do engajamento do homem de ciência nas causas político-sociais do seu tempo. O que prevalece nos tempos hodiernos é o papel do cientista que, da mesma forma em que trata o seu objeto de pesquisa - mito da neutralidade científica posta-se diante das questões sociais. Trata-se de uma pseudonoção, que Einstein rejeitava, a de que o cientista é aquele que está desconectado do mundo, vivendo em uma realidade paralela, indiferente à ordem e aos problemas sociais, reduzido ao micromundo do seu laboratório ou do seu gabinete de pesquisa, rejeitando todo e qualquer envolvimento que, enganosamente, cognomina "político".

\section{Einstein: religião e religiosidade cósmica}

Apesar da influência da moral judaica na sua vida, Einstein tinha clareza dos limites e da extensão das fronteiras que delimitam o campo científico e o separa da fé religiosa. Para ele, a crença generalizada intrínseca ao campo científico é a de que, no âmbito da confiança no princípio da causalidade, não há lugar para a 
"crendice" em um ser que venha interferir na ordem da natureza. Como consequência disso, não há lugar para um Deus criador, antropomorfizado, que castiga e consola, e que intervém no destino do cosmo. No âmbito da causalidade o que existe é a explicação de que "o homem age segundo leis rigorosas internas e externas, que lhe proíbem rejeitar a responsabilidade sobre a hipótese-Deus, do mesmo modo que um objeto inanimado é irresponsável por seus movimentos" (EINSTEIN, 1981, p. 22). Com isso, além da clara delimitação entre esses dois campos da criação humana (religião e ciência), fomenta-se, entre os cientistas e os homens de fé, o caráter de oposição e combate. Por um lado, há a crença de que a ciência prejudica a moral religiosa - "coisa absolutamente injustificável", segundo Einstein; por outro lado, há a crença de que a religião constitui campo propício para o retrocesso cognitivo e criativo da humanidade. Esse tipo de enviesamento acaba por excitar um embate permanente entre esses dois campos.

Um conflito surge, por exemplo, quando uma comunidade religiosa insiste na absoluta veracidade de todos os relatos registrados na Bíblia. Isso significa uma intervenção da religião na esfera da ciência; é aí que insere a luta da Igreja contra as doutrinas de Galileu e Darwin. Por outro lado, representantes da ciência têm constantemente tentado chegar a juízos fundamentais com respeito a valores e fins com base no método científico, pondo-se assim em oposição à religião. Todos esses conflitos nasceram de erros fatais. (EINSTEIN, 1994, p. 29)

Einstein, contudo, vê as coisas de um modo diferente. Para ele, religião e ciência são parte de um mesmo propósito que está ligado ao ato de crer, no sentido mais forte da palavra, isto é, de acreditar em algo que está subjacente à realidade imediata. Entretanto, a ciência é aquela que se preocupará com o conhecimento do que é e, ao fazer isso, abre as portas ao conhecimento do que deve ser, que deve emanar de outra fonte, nesse caso, da religião. Não se trata, contudo, da defesa de uma concepção de inter-relacionamento baseado em qualquer tipo de dependência, ou mesmo de uma relação de subordinação e nem de superioridade de um campo em relação ao outro. Trata-se de uma noção peculiar do modo de ver e entender a ciência que, ao se preocupar com o conhecimento do que é, abre-se a uma perspectiva de vivência de uma genuína concepção de religiosidade cósmica ${ }^{1}$. Tal concepção não fora sistematicamente trabalhada por Einstein; são os seus exemplos que nos fazem conjecturar sobre o que ele estava tratando.

Quando Einstein apresenta nomes vinculados ao que ele entende por religião cósmica - nomes como o de Davi (nos Salmos), Demócrito, Francisco de Assis e Spinoza, passando também pelo budismo - deixa-nos claro que se tratava de um protótipo de religião sem dogmas, sem um conceito determinado de Deus, um ser concebido como imagem do homem ou vice-versa, antropomórfico, etc. Consequentemente, nesse tipo de religião também não há lugar para a teologia e nem para igrejas. Mesmo sendo de origem judaica, Einstein não alimentava qualquer apreço por qualquer tipo de religião institucionalizada, a não ser pelos aspectos da moralidade e da tradição. Segundo afirma, "não posso considerar as tradições confessionais a não ser pelo ponto de vista da história ou da psicologia. Não tenho outra relação possível com elas" (EINSTEIN, 1981, p. 209). Por outro lado, quanto à religiosidade cósmica, Einstein defende que, todos "os gênios-religiosos de todos os tempos se distinguiram por essa religiosidade ante o cosmos", bem como "os hereges de todos os tempos da história humana se nutriam com essa forma superior de religião" (EINSTEIN, 1981, p. 22). Apesar de lhe dar o nome de religiosidade cósmica, ainda assim, ele "não podia falar dela com facilidade já que se trata de uma noção muito nova, à qual não corresponde conceito algum de um Deus antropomórfico" (EINSTEIN, 1981, p. 20). Se assim o é, ao que corresponde esse tipo de religiosidade? E o que ela tem a ver com a ciência?

Para Einstein, "a religião cósmica é o móvel mais poderoso e mais generoso da pesquisa científica" (EINSTEIN, 1981, p. 22). Tal religiosidade não é mais do que uma convicção que é comparável à convicção religiosa em geral. "Esta convicção, ligada ao sentimento profundo de uma razão superior, desvendando-se no mundo da experiência, traduz para mim a ideia de Deus. Em palavras simples, poder-se-ia traduzir,

1 Algumas vezes Einstein usa a expressão “religiosidade cósmica", outras vezes, "religião cósmica”. Em ambos casos, os sentidos são esvaziados de qualquer conotação institucionalizada ou confessional de religião. 
como Spinoza, pelo termo 'panteísmo"' (EINSTEIN, 1981, p. 209). Ela sugere a existência de um Universo geometricamente ordenado, racional, inteligível e eterno, livre das incertezas e contingências e sem necessidade de complementaridades do tipo daquelas oferecidas por Bohr na Interpretação de Copenhague da mecânica quântica. Somente quem vivencia as maravilhas das criações intelectuais inovadoras, desprovidas dos compromissos da vida prática, pode experimentar-se como parte da religiosidade cósmica. Eis que essa noção é parecida com um estado permanente de satisfação e plenitude, felicidade e conhecimento, obtidos dos "gigantescos esforços" geradores das maiores inovações no campo científico que, segundo Einstein, devem estar descompromissados do caráter utilitário e imediatista da vida prática. "Aquele que só conhece a pesquisa científica por seus efeitos práticos vê depressa demais e incompletamente a mentalidade de homens que, rodeados de contemporâneos céticos, indicaram caminhos aos indivíduos que pensavam como eles" (EINSTEIN, 1981, p. 22-23).

Em uma época como a nossa, em que estamos mergulhados no materialismo, o reconhecimento dos espíritos profundamente religiosos geralmente está atrelado aos sábios escrupulosamente honestos, segundo Einstein (EINSTEIN, 1981, p. 23). O espírito científico, portanto, não existe sem esse tipo de religiosidade cósmica que, via de regra, está associada também à noção aristotélica de "espanto", da qual nasce, segundo Aristóteles, o conhecimento filosófico. A diferença, entretanto, é que, no caso de Einstein, tal espanto não desempenha somente a função de uma força motriz com a qual se inicia o processo do conhecimento. Nesse caso, trata-se de um "espantar" ou um "extasiar" permanente do cientista frente à harmonia da natureza, cujos efeitos da "contemplação" são geradores do próprio entendimento das leis da natureza, "revelando uma inteligência tão superior que todos os pensamentos humanos e todo seu engenho não podem desvendar" (EINSTEIN, 1981, p. 23). É justamente isso que pode ser entendido por religiosidade da pesquisa, ou religiosidade cósmica: uma espécie de olhar silencioso e solitário para a ordem do Universo, sob o pretexto de desvelá-lo - mesmo que de "modo irrisório" -, sabedores que somos da existência da ordem, da causalidade, do determinismo e da existência de uma realidade externa independente da percepção subjetiva (realismo). Esse tipo de concepção vai ao encontro da crença de que não há acaso e que há uma conexão implícita da parte com o todo, cujo trabalho solitário de desvelamento constitui um verdadeiro ato de fé e de contemplação. Nisso constitui o trabalho da ciência que, segundo Einstein, só pode ser criada por quem esteja plenamente imbuído da aspiração à verdade e ao entendimento, cujas fontes brotam na esfera da religião. "Não posso conceber um autêntico cientista sem essa fé profunda. A situação pode ser expressa por uma imagem: a ciência sem religião é aleijada, a religião sem a ciência é cega" (EINSTEIN, 1994, p. 30).

A única concessão feita por Einstein no que diz respeito à interconexão entre ciência e religião, diz respeito a como a religião conceitua Deus. Segundo ele, a imagem do Deus onipotente, onipresente e onisciente é resultado do que ele chama de "período juvenil da evolução espiritual da humanidade", fruto da fantasia humana que criou deuses para lhe apaziguar frente aos fenômenos inexplicáveis da vida e da natureza. A imagem desse Deus que interfere, consola, conforta, orienta, castiga, comunica-se, denuncia de si uma vulnerabilidade que lhe é inerente: se cada atitude do homem é conduzida por esse Deus, como responsabilizá-lo perante ao todo-poderoso? "Ao distribuir punições e recompensas, Ele estaria, até certo ponto, julgando-se a Si mesmo. Como conciliar isso com a bondade e a justiça a Ele atribuídas?" (EINSTEIN, 1994, p. 31). É justamente na esfera da aceitação de um Deus pessoal, antropomorfizado, que consiste o desacordo entre ciência e religião, pois sendo a ciência um campo em que se pretende estabelecer regras gerais que determinam a conexão recíproca de objetos e eventos no tempo e no espaço, não há lugar para explicações causais que admitam esse tipo de imagem. Somente por meio do conhecimento científico somos capazes de conhecer as leis da natureza, as suas regularidades, o comportamento temporal dos fenômenos naturais, calcular com exatidão as trajetórias planetárias e entender a regularidade dos sistemas vivos. Só nos falta, segundo o projeto que Einstein perseguiu por toda sua vida, o conhecimento do caráter profundamente geral das conexões, isto é, a busca da unificação racional do múltiplo ${ }^{2}$. Somente aquele que experimentou intensamente os avanços bem-sucedidos nesse domínio, movidos por uma profunda reverência pela racionalidade

2 Tratou-se de um projeto de vida de Einstein, por exemplo, encontrar uma teoria que unificasse os campos gravitacional e eletromagnético. 
implicada na existência do cosmo, pode experimentar a atitude mental de humildade perante à grandeza da razão que se esconde nessa mesma existência. É justamente esse caráter de contemplação e entendimento da racionalidade recôndita na grandeza da existência que configura, segundo Einstein, uma atitude religiosa no sentido mais profundo da palavra. "A meu ver, portanto, a ciência não só purifica o impulso religioso do entulho de seu antropomorfismo, como contribui para uma espiritualização religiosa de nossa compreensão da vida" (EINSTEIN, 1994, p. 33).

Quanto mais avança a evolução espiritual da humanidade, mais certo me parece que o caminho para a religiosidade genuína não passa pelo medo da vida, nem pelo medo da morte, ou pela fé cega, mas pelo esforço em busca do conhecimento racional. Neste sentido, acredito que o sacerdote, se quiser fazer jus à sua sublime missão educacional, deve tornar-se um professor. (EINSTEIN, 1994, p. 34)

Dessa forma, a religião confessional seria desprezada caso a sua missão não se restringisse à contribuição para o desenvolvimento racional (sacerdote tornando-se professor) ${ }^{3}$ e à propagação dos valores morais historicamente desenvolvidos pela tradição, valores estes, pelos quais Einstein tinha grande apreço. A ciência, por outro lado, continuaria na sua "religiosa" busca pela inteligibilidade da ordem do Universo e das leis que o sustenta.

\section{O engajamento político como dever do homem de ciência}

Além dessa responsabilidade pela busca do entendimento da ordem da natureza, que pressupõe renúncia, isolamento, solidão, reflexão e austeridade, ainda assim, tal atividade não pode eximir o cientista do seu compromisso social. Einstein foi a prova de que é possível ser homem de ciência e cidadão do mundo. Do alto da autoridade de um dos mais importantes cientistas do século XX, ele não abdicou de uma vida ativa em prol da luta em favor das causas mais sublimes do seu tempo. A roupagem de cientista alienado e alheio aos problemas da vida não lhe servia. Cunhou posicionamentos críticos para o seu tempo que eram cruciais para a manutenção da vida e da paz. Envolveu-se com temas que, certamente, a ciência ortodoxa de todos os tempos os rejeitariam. Foi corajoso! Mas, qual era de fato a concepção pessoal de Einstein quanto ao papel da ciência e da atuação do cientista? Como ele via a relação entre ciência e vida? Como suas impressões deixaram marcas na história e historiografia da ciência?

Cremos que tudo tenha começado muito cedo. A formação moral de Einstein foi deveras marcante a ponto de imprimir-lhe comportamentos que se reiteraram durante toda sua vida. A começar pela sua infância, Einstein, quando garoto, segundo seus biógrafos, rejeitava brincar com soldadinhos, bem como se vestir ou representar papel de soldado. Aos 17 anos abriu mão da nacionalidade alemã para fugir do serviço militar. A rejeição por tudo que fosse associado à destruição e à guerra acompanhou-o por toda a sua vida. Ele sempre se opôs ao uso da força militar e rejeitou qualquer modelo educacional que estivesse envolvido com o militarismo. Tal envolvimento, para Einstein, incorreria num desastre psicológico de uma nação e na morte dos direitos dos indivíduos. Em 1930, Einstein escreveu:

A pior das instituições gregárias se intitula exército. Eu o odeio. Se um homem puder sentir qualquer prazer em desfilar aos sons de música, eu desprezo este homem... Não merece um cérebro humano, já que a medula espinhal o satisfaz. Deveríamos fazer desaparecer o mais depressa possível este câncer da civilização. Detesto com todas as forças o heroísmo obrigatório, a violência gratuita e o nacionalismo débil. A guerra é a coisa mais desprezível que existe. Preferiria deixar-me assassinar a participar desta ignomínia. (EINSTEIN, 1981, p. 12)

3 Lembre-se que Einstein foi defensor do racionalismo crítico e do realismo. 
Havia em Einstein uma firme convicção de que a violência fascina os seres moralmente fracos, entretanto, ele confiava mais na massa sem formação do que no comportamento moral de muitos intelectuais. Muitas vezes exortou, como em carta a Sigmund Freud, pela associação livre de personalidades intelectuais e morais em favor do que ele chamou de "programa realmente novo", isto é, a criação de uma comunidade internacional que pudesse exercer uma influência significativa e moralmente sadia na resolução de problemas políticos apoiando, por exemplo, a Sociedade das Nações naquilo que consagrou a sua criação (EINSTEIN, 1981). É claro que Einstein foi feliz e saiu vitorioso em muitas das suas lutas, entretanto, não foram somente louros que colheu em suas empreitadas. Na luta contra o nacionalismo, o qual ele tanto odiava, viu-se, por vezes, digladiando contra aqueles que no passado estiveram do seu lado. Isso é o que demonstra, por exemplo, as suas correspondências à Academia das Ciências da Prússia e à Academia das Ciências da Baviera quando delas se desligou. Contudo, pior do que isso, foi ver-se envolvido na rejeição de atitudes nacionalistas de seus próprios amigos, como foi o caso da decepção de ter visto amigos como Max Planck, Walther Nernst e Fritz Haber ${ }^{4}$ assinarem, em 1914, juntamente com 90 figuras de destaque alemãs do mundo das artes, humanidades e ciências, o afamado Manifesto para o Mundo Culto: um documento que protestava contra "as mentiras e difamações com as quais nossos inimigos estão tentando denegrir a causa pura da Alemanha na difícil luta de vida ou morte, na qual ela foi lançada" (ROBINSON, 2005, p. 158). A partir de então, Einstein começa a declarar-se publicamente a respeito do seu posicionamento político no mundo, assinando um contramanifesto intitulado Manifesto aos Europeus. Esse fato marcou o início da sua atuação política e selou de vez a sua visão do que deveria ser a atuação do cientista.

Para Einstein, a primeira função social do cientista é lutar pela promoção da paz, seguida do ordenamento social em prol da justiça e da liberdade. Sendo assim, suas primeiras frentes de batalha foram contra as correntes ultranacionalistas que, travestidas de patriotismo cego, promoviam as maiores barbáries contra a espécie humana. Dessa forma, o fascismo italiano e o socialismo russo foram os seus primeiros alvos. "(...) Luto sem tréguas e apaixonadamente contra os sistemas dessa natureza, contra a Itália fascista de hoje e contra a Rússia soviética de hoje" (EINSTEIN, 1981, p. 11). Atrelada a esses combates, encontra-se a luta permanente de Einstein contra o nacional-socialismo, ou nazismo, na Alemanha que não é mais do que uma forma de fascismo que agrega o racismo científico e o antissemitismo, além de apoiar teorias como a da hierarquia racial e do darwinismo social, dado a ideologia pangermânica de extrema-direita que acreditava que os povos germânicos eram os mais puros da raça ariana e, portanto, vistos como a "raça superior".

Contra o fascismo, além das diversas manifestações públicas proclamadas por Einstein, houve uma intervenção que fora mais direta. Trata-se do fato de ele rogar ao ministro Rocco, em Roma, para que intercedesse, a fim de evitar que cientistas viessem sofrer de cruel iniquidade na Itália. Diz Einstein (1981, p. 26): "Eu vos peço, portanto, que aconselheis o Senhor Mussolini no sentido de que se evite esta humilhação para a nata da inteligência italiana". Tudo isso, em nome da liberdade de opinião e ensino, conquistadas a duras penas pelos italianos desde os tempos da Renascença na Itália, razão pela qual ela se tornou amada e honrada por todos. E sem entrar nas "razões de Estado" que pudessem justificar as investidas de Mussolini contra a ciência de sua época, Einstein insiste que "o combate pela verdade científica, afastados dos problemas concretos da vida cotidiana, deveria ser considerado intocável pelo poder político" (EINSTEIN, 1981, p. 26).

Em dois outros momentos, Einstein reiterou publicamente o seu combate ao fascismo em veículos de imprensa como o New York Times, onde se manifestou sobre os riscos do fascismo e sobre a necessidade de um refreamento de sua ação e expansão. Na primeira vez, em 1939, portanto no início da Segunda Guerra Mundial, convidado a exprimir-se brevemente sobre o perigo do fascismo, Einstein tomou como base de sua resposta a questão do desemprego. Trata-se de uma reflexão atual visto que as mesmas ameaças de outrora ressurgem mundo afora, especialmente no presente contexto político brasileiro. Sabe-se que a questão do desemprego e a crise econômica podem funcionar como mola propulsora para a introdução do fascismo nas

4 Max Planck se arrependeu de ter assinado o manifesto, mas por ser um notório conservador, acabou cortando a amizade com Einstein por não simpatizar nem pelo seu pacifismo e nem pela defesa dos judeus. O químico Fritz Haber tornou um desenvolvedor de armas químicas para o nazismo que mataram milhares de soldados em campo de guerra e milhões de judeus em campos de concentração. E o amigo Nernst tornou-se também um homem belicoso. 
camadas sociais desfavorecidas e essa era a preocupação de Einstein. Com o fascismo instalado, vêm todos os tipos de infortúnios que vão desde a militarização de todos os âmbitos da vida (educação, ciência, governança, etc.) até a perseguição às liberdades individuais sob toda forma de repressão. No que diz respeito à análise feita por Einstein, se havia uma unanimidade entre os americanos de que o fascismo constituía um mal que deveria ser combatido, não havia unanimidade sobre com quais os meios isso devia ser feito. Dessa forma, ele elege o desemprego como ponto de partida para o entendimento do problema e consequente busca de solução.

Segundo Einstein, "não é sem dificuldades nem reticências que o homem renuncia às suas liberdades e aos seus direitos. Mas basta que um povo se veja, em grande parte, confrontado com uma situação insuportável para que se torne incapaz de um julgamento são e se deixe abusar voluntariamente por falsos profetas" (EINSTEIN, 1939, p. 1). E é justamente o desemprego, juntamente com a tensão de empregos sem garantia de estabilidade, que faz com que o homem se torne vulnerável aos falsos profetas. É aqui que está o perigo político do desemprego, pois na situação de desempregado o cidadão acaba por conceder, sem discernimento, "a sua confiança ao primeiro que chegue a prometer-lhe uma melhora da sua situação" (EINSTEIN, 1939, p. 3). O que justifica a vulnerabilidade do desempregado, segundo Einstein, é que:

O desempregado não sofre somente por estar privado de bens de primeira necessidade. Ele sente-se ainda excluído da comunidade humana. Ele vê recusada a possibilidade de colaborar no bem-estar geral; não goza de nenhuma consideração, sendo mesmo percebido como um fardo. É absolutamente natural que ele tenha o sentimento de que nós procedemos incorretamente perante ele e que, procurando desembaraçar-se por si mesmo, tenha pouco a pouco recorrido a meios ilegais, a atos criminosos. (EINSTEIN, 1939, p. 2)

E é em virtude desse fato que Einstein coloca-se convencido de que somente medidas eficazes contra o desemprego e a insegurança econômica do indivíduo poderá afastar o fantasma do fascismo. Trata-se de um caminho - que não é exclusivo - para a derrocada do fascismo. Até porque, em tempos de crise econômica, segundo Einstein, os jovens são os mais afetados pelo desemprego, tornando-se eles, pela falta de experiência, cegos aos perigos e arriscados a se comportarem de maneira irrefletida. A pergunta de Einstein, portanto, é sobre se não seria justificável sacrificar parte da liberdade econômica se isso permitisse a garantia da segurança do indivíduo e da comunidade, isso porque, "trata-se de nos defendermos contra um perigo que a todos diz respeito" (EINSTEIN, 1939, p. 2). Sendo assim, é necessário "impormo-nos voluntariamente limites em favor de uma ordem cuja necessidade reconhecemos é na verdade, em geral, o meio mais eficaz para chegar ao mais alto grau possível de liberdade e de segurança, inclusive no domínio da política internacional" (EINSTEIN, 1939 , p. 5). Combater o desemprego é um dos caminhos para se chegar a essa ordem.

Nem mesmo setores do sionismo escaparam da denúncia do caráter fascista por parte de Einstein. Em uma carta enviada, em 1948, ao editor do New York Times, assinada por Einstein, Hannah Arendt e mais 22 judeus de Nova Iorque, houve a denúncia das motivações fascistas do líder do Tnuat Haherut (Partido da Liberdade) israelense, Menachem Begin, quando da sua visita aos Estados Unidos. Segundo a denúncia:

\footnotetext{
Entre os fenômenos políticos mais perturbadores de nossos tempos está a emergência no recém-criado Estado de Israel do "Partido da Liberdade" (Tnuat Haherut), um partido político estreitamente assemelhado em sua organização, métodos, filosofia política e apelo social ao nazista e a partidos fascistas. O partido foi formado a partir de membros e seguidores do antigo Irgun Zvai Leumi, uma agremiação terrorista, de direita e chauvinista existente na Palestina. (EINSTEIN et al., 1948, p. 2)
}

Segundo os signatários da carta, a visita de Begin aos Estados Unidos teria como intensão criar uma impressão de que o povo americano estaria apoiando o partido para as próximas eleições do recém-formado Estado de Israel, bem como para ganhar a simpatia dos sionistas conservadores naquele país. Isso poderia gerar um prejuízo irreparável, já que até financiamento esse grupo poderia conseguir com as manifestações 
públicas de apoio a Begin por parte dos americanos. O comportamento do líder do Partido da Liberdade, contudo, faz crer na verdade de seu caráter: "agora falam de liberdade, de democracia e de anti-imperialismo, mas recentemente pregavam a doutrina do Estado fascista" (EINSTEIN et al., 1948, p. 2). Para evidenciar a aparência enganadora do partido de Begin, os autores, liderados por Einstein, apresentam exemplos de suas ações no passado, para revelar o que o povo poderia encontrar no futuro: 1) atacaram a pacífica aldeia árabe de Deir Yassin onde mataram 240 homens, mulheres e crianças e os que restaram vivos tornaram-se cativos; 2) pregam de uma mistura de ultranacionalismo, misticismo religioso e superioridade racial na comunidade judaica; 3) tal como outros partidos fascistas, furam greves e apostam na destruição de sindicatos - propõem sindicatos corporativos aos moldes do fascismo italiano; 4) lançam terror na comunidade judaica palestina; 5) espancaram e assassinaram professores que se colocaram contra eles; 6) por métodos de gângster, espancamentos, chantagem e roubos em larga escala, os terroristas intimidam a população e exigem pagamento de um pesado tributo. Estas são apenas algumas das ações que evidenciavam as contradições observadas entre o Begin que se apresentava nos Estados Unidos em busca de apoio e os comportamentos do seu partido, comportamentos estes, que denunciavam quão perigosa era aquela organização. Segundo os autores, capitaneados por Einstein, "esta é a marca inconfundível de um partido fascista, para quem o terrorismo (indiscriminado contra judeus, árabes e britânicos) e o embuste são os meios e um Estado Líder é o objetivo" (EINSTEIN et al., 1948, p. 3). Sendo assim, os que assinaram a carta ao editor do New York Times recomendaram aos americanos a não apoiarem esta "última manifestação do fascismo" no mundo.

Contra o socialismo soviético, há uma passagem que resume bem o posicionamento de Einstein. Trata-se de uma resposta a uma carta aberta de quatro cientistas russos soviéticos ${ }^{5}$, cuja tônica principal foi o ataque contra a noção de "governo mundial" defendida por Einstein e sobre os possíveis efeitos maléficos contra a paz que esse tipo de noção poderia causar. Em resumo, a queixa geral era a de que a defesa enfática de Einstein de um governo mundial seria nada mais que a tentativa de consolidação do domínio capitalista sobre os Estados individuais. Essa tentativa de domínio teria como principal interessado e líder os Estados Unidos, uma vez que, depois da Segunda Guerra Mundial, o que se via era sua perda de território de exploração capitalista frente a um processo mundial de descolonização e independência de diversos países. Para os cientistas russos, essas "ideias progressistas", defendidas por Einstein,

(...) são reflexo do fato de que os monopólios capitalistas, que dominam os grandes países industriais, consideram suas fronteiras nacionais demasiado estreitas. Precisam de um mercado de âmbito mundial, de fontes de matéria-prima de extensão mundial e de esferas mundiais de investimento de capital. Graças ao seu domínio nas questões políticas e administrativas, os interesses monopolistas das grandes potências estão em condições de utilizar a máquina governamental em sua luta por esferas de influência e em seus esforços para subjugar econômica e politicamente outros países, para neles bancar os patrões tão livremente quanto nos seus próprios. (apud EINSTEIN, 1994, p. 172)

Como evidências do que aqui se afirma, os cientistas russos soviéticos apresentam uma série de fatos que endossavam as suas percepções: o histórico americano de subjugação de nações dependentes, a luta pela manutenção do monopólio econômico pelos países imperialistas, a influência dos países imperialistas nas eleições nacionais de países coloniais dependentes, a manipulação da imprensa em favor de campanha favorável ao modelo capitalista, a utilização da ONU para "adaptar as políticas externas às exigências de Washington", a manipulação dos votos na Assembleia Geral em favor do seu "virtual patrão", o uso do poder de veto na Assembleia Geral para contornar situações que favoreçam aos Estados Unidos, etc. A ideia de um governo mundial ante a esses expedientes, segundo os cientistas russos, iria somente sedimentar e fortificar "a expansão desenfreada do imperialismo norte-americano e desarmar ideologicamente as nações que insistem em manter a sua independência" (apud EINSTEIN, 1994, p. 177). Em virtude disso, perguntam: "será que Einstein não percebe o quanto esses planos seriam fatais para a segurança e a cooperação internacionais?"

5 Carta aberta enviada por Sergei Vavilov, A. N. Frumkin, A. F. Joffe e N. N. Semynov. 
Defendem, por fim, que a manutenção dos Estados independentes não é empecilho para a cooperação política e econômica, desde que, as diferenças entre os países sejam respeitadas. Encerram, portanto, com as escusas a Einstein por terem se posicionado com "absoluta franqueza e sem floreios diplomáticos".

Subtraindo a defesa do sistema e ações americanas feita por Einstein em carta resposta, bem como a apologia velada feita aos Estados Unidos, interessa-nos sua visão acerca de como ele via o sistema soviético contra o qual, juntamente com o fascismo italiano, ele havia prometido lutar. Sabemos que União das Repúblicas Socialistas Soviéticas (URSS) foi um Estado socialista que existiu de 1922 a 1991. Sabemos também o apreço manifesto de Einstein pelo modelo de economia socialista que, desprovido dos seus vícios de centralização de poder político e econômico, bem como da perda dos direitos pelo indivíduo e do poder da burocracia, poderia constituir um bom caminho para um mundo melhor, conforme ele escreve em 1949:

Estou convencido de que há apenas um meio de eliminar esses graves males: o estabelecimento de uma economia socialista, acompanhado de um sistema educacional orientado para fins sociais. Numa tal economia, os meios de produção pertencem à própria sociedade e são utilizados de maneira planejada. Uma economia planejada, que ajuste a produção às necessidades da comunidade, distribuiria o trabalho a ser feito entre todos os que tivessem a capacidade para trabalhar e garantiria a subsistência de todo homem, mulher e criança. A educação do indivíduo, somada à promoção de suas capacidades inatas, buscaria desenvolver nele um senso de responsabilidade por seus semelhantes, no lugar da glorificação do poder e do sucesso de nossa sociedade atual. (EINSTEIN, 1994, p. 136)

Mas, não era isso que Einstein via no sistema soviético contra o qual ele se propôs outrora lutar e em sua resposta aos cientistas russos soviéticos aparece-nos o que ficou de mais forte em suas impressões. Interessante notar que a resposta de Einstein não se inicia com as questões objetivas colocadas pelos cientistas - sobre isso ele trata no final -, mas com as questões subjetivas, de entrelinhas, que podem representar aquilo que, no mais íntimo, é a causa do incômodo dos seus adversários. Trata-se de um procedimento típico de uma mente arguta que sabe como construir um argumento que desestabilize o seu interlocutor. E o início da resposta encaminha-se por uma "constatação" de Einstein: "acredito que por trás dessa fachada agressiva exista uma atitude mental defensiva, que nada mais é que a tendência a um isolamento quase ilimitado" (EINSTEIN, 1994, p. 178 - grifos nossos). E o que justifica esse isolamento adotado pelos russos soviéticos? Segundo Einstein, foram as três últimas décadas de ataques estrangeiros contra aquele povo: invasões alemãs, intervenções estrangeiras durante a guerra civil, campanha caluniosa da imprensa ocidental e o apoio de Hitler para combater a Rússia. Contudo, "por mais compreensível que seja esse desejo de isolamento, ele continua sendo não menos desastroso para a Rússia e todas as outras nações" (EINSTEIN, 1994, p. 179).

Outra "atitude mental defensiva" identificada por Einstein na carta aberta dos cientistas russos é a obsessão quase que paranoica que eles têm pelo antagonismo entre capitalismo e socialismo e que domina todas as suas ideias sobre os problemas internacionais. Para Einstein, tal paranoia não se justifica, até porque, ele também partilha da ideia de que "uma economia socialista possui vantagens que contrabalançam inquestionavelmente suas desvantagens, sempre que a administração alcance, pelo menos em certa medida, padrões adequados" (EINSTEIN, 1994, p. 179). E os padrões adequados entendidos por Einstein dizem respeito, conforme supramencionado, a uma economia planejada, em que haja a descentralização de poder político e econômico, e sem a perda dos direitos do indivíduo em favor da supervalorização da burocracia. Segundo Einstein, caso um sistema dessa qualidade venha a acontecer, as nações de todo o mundo irão agradecer à Rússia por ter atingido tão alto grau de economia planejada. Por outro lado, ele não vislumbra que o capitalismo possa fazer isso, muito menos que consiga controlar o desemprego que se tornará crônico, na medida em que o progresso técnico torna-se incapaz de manter o equilíbrio entre produção e poder de compra. Entretanto, diz Einstein, "não devemos cometer o erro de condenar o capitalismo por todos os males sociais e políticos existentes e de presumir que a implantação do socialismo, por si só, seria capaz de curar todas as mazelas sociais e políticas da humanidade" (EINSTEIN, 1994, p. 180). Se assim é, onde estaria o perigo do socialismo russo contra o qual Einstein prometeu lutar? 
O perigo dessa crença reside, em primeiro lugar, no fato de ela encorajar a intolerância fanática de todos os "crentes", ao transformar um método social possível numa espécie de igreja que rotula todos os que não pertencem a ela como traidores ou sórdidos malfeitores. Uma vez alcançado esse estágio, a capacidade de entender as convicções e ações dos "incrédulos" desaparece por completo. Tenho certeza de que os senhores sabem, através da história, quanto sofrimento desnecessário tais crenças rígidas infligiram à humanidade. (EINSTEIN, 1994, p. 180 - grifos nossos).

Para a mentalidade de Einstein, qualquer governo que se degenere em tirania é um mal em si. Contudo, ter um governo representa um mal que é necessário, visto da necessidade da promoção de um equilíbrio dinâmico entre as vontades do povo e as do governo que deve representar as "vontades" do próprio Estado, fixadas na forma da Lei. O perigo se potencializa em nações em que o governo administra com o uso das forças militares e do controle dos canais de educação e imprensa, bem como surrupiando os direitos econômicos dos cidadãos. É por isso que o socialismo aos moldes dos russos soviéticos, para Einstein, "não pode ser considerado a solução para todos os problemas sociais, mas uma mera estrutura em que essa solução é possível" (EINSTEIN, 1994, p. 180). Nota-se que Einstein não nega o socialismo como tal, mas admite que aos moldes como as coisas foram feitas na Rússia soviética, só serviriam como uma "estrutura possível" de solução para os problemas sociais. Sendo assim, qual deveria ser a atitude dos russos frente aos problemas internacionais dos quais eles, naquela época, preferiam manter-se em estado de isolamento externo e de controle interno com mão de ferro? Seria exatamente sair do estado de isolamento e investir seus esforços em prol de um mundo sem guerras, adotando uma atitude pacifista e diminuindo a tensão entre as fronteiras dos Estados livres.

Será realmente inevitável que, por causa de nossas paixões e costumes herdados, estejamos condenados a aniquilar uns aos outros tão completamente que não sobre nada digno de ser conservado? Não é verdade que todas as controvérsias e divergências de opinião em que tocamos, em nossa estranha troca de cartas, são ninharias insignificantes, se comparadas ao perigo em que todos nos encontramos? Não deveríamos fazer tudo que estiver ao nosso alcance para eliminar o perigo que ameaça igualmente todas as nações? (EINSTEIN, 1994, p. 184)

Einstein termina por dizer que os seus objetivos na defesa da criação de um governo mundial, diferentemente do que pensam os colegas russos, está no fato de ele crer que não há outra maneira de se evitar o perigo que se avizinhava, que era o do aniquilamento total da raça humana, cuja responsabilidade de evitar seria de todos.

Quanto à luta contra o nacional-socialismo alemão, essa é um pouco mais longa na história de Einstein. Já havíamos falado sobre a sua aversão, desde criança, a tudo que dizia respeito ao mundo militar e das armas. Entretanto, conforme vimos, foi somente em 1914 que Einstein se pronuncia publicamente, pela primeira vez, em assuntos políticos quando assina o Manifesto aos Europeus, elaborado pelo médico fisiologista alemão Georg Friedrich Nicolai. Tratou-se de um manifesto em rejeição ao Manifesto para o Mundo Culto, assinado por 93 figuras de destaque do mundo culto alemão, que defendia a Alemanha das acusações daqueles que tentavam difamar a "causa pura" do povo alemão. O Manifesto aos Europeus não se envolveu diretamente nas polêmicas sobre o que justificava a guerra e nem tratou dos possíveis culpados, "em vez disso, utilizando de uma linguagem propositadamente contida, exortava as pessoas educadas de todas as partes a tentar 'criar uma unidade orgânica na Europa"' (ROBINSON, 2005, p. 158). Esse manifesto circulou, desde 1914, entre os intelectuais alemães, conseguindo muito apoio - inclusive de Planck que havia se arrependido de assinar o manifesto nacionalista -, mas, ninguém mais ousou assiná-lo a não ser G. F. Nicolai, Einstein e um desconhecido. Consequência disso, foi que o mesmo só foi publicado em 1917 e, ainda assim, em Zurique e não em Berlim. A partir de então, Nicolai foi perseguido pelos ultranacionalistas que conseguiram arruinar a sua carreira obtendo a proibição, em 1920, de que ele continuasse lecionando. Com o nacionalismo crescente, 
houve o boicote aos "pesquisadores inimigos", que não podiam sequer serem citados, chegando ao limite de, em duas décadas depois, já com Hitler no poder, nem mesmo referências a físicos judeus poderem ser feitas, principalmente dos trabalhos de Einstein, a não ser que o caráter da referência fosse para contradizer as suas teorias. “(...) No caso dos nazistas, isso era uma ordem do governo, com punições severas aos infratores. O que é particularmente lamentável sobre a autocensura alemã durante a Primeira Guerra Mundial é o fato de ter sido totalmente voluntária" (ROBINSON, 2005, p. 159).

Durante a Primeira Guerra Mundial, Einstein esteve envolvido, por exemplo, no desenvolvimento da Teoria Geral da Relatividade (1915) e não se pronunciou politicamente a não ser em alguns episódios com a Liga de Goethe de Berlim e em alguns escritos aos seus amigos. E, justamente por causa desses amigos - Planck, Max Born, Max von Laue - ele não teve coragem de deixar a Alemanha assim que terminou a Primeira Guerra Mundial. Nem mesmo a oferta de Hendrik Lorentz de levá-lo para a Holanda em 1919, fez com que Einstein deixasse a Alemanha em uma hora que ele via ser de maior necessidade. Com a tomada de poder pela República de Weimar, em 1919, Einstein acreditava que, mesmo com o crescimento de partidos de extrema-direita e do antissemitismo, ainda assim, era possível continuar e combater esse estado de coisas. Mas as coisas pioraram entre 1919 e 1920 quando a campanha antissemítica contra Einstein aumentou em virtude de sua fama e projeção mundial. "Seu pacifismo declarado e seus pronunciamentos políticos diretos, porém, incandesceram o abuso - incluindo seu compromisso com a causa sionista em 1919 e nos anos seguintes" (ROBINSON, 2005, p. 163). O ápice da resistência àquela situação, por parte de Einstein, foi o dia 7 de novembro de 1923 quando ele recebeu uma ameaça de morte depois de os jornais alemães publicarem uma matéria falsa (fake news) sobre sua visita à União Soviética - isso foi um verdadeiro "osso" para os ultranacionalistas radicais.

Einstein acabou por se refugiar em Leiden com Lorentz e alguns amigos e, mesmo sendo advertido por Planck em não se envolver com as questões de política interna na Alemanha, ainda assim, continuou com sua causa pacifista e contra o serviço militar obrigatório.

O nacionalismo, hoje espalhado por toda parte de maneira tão perigosa, se desenvolve perfeitamente a partir da criação do serviço militar obrigatório, ou, belo eufemismo, do exército nacional. Exigindo dos cidadãos o serviço militar, o Estado se vê obrigado a neles exaltar o sentimento nacionalista, base psicológica dos condicionamentos militares. Ao lado da religião, o Estado deve glorificar em suas escolas, aos olhos da juventude, seu instrumento de força brutal.

A introdução do serviço militar obrigatório, eis a principal causa, a meu ver, da decadência moral da raça branca. (EINSTEIN, 1981, p. 76-77)

Em virtude dessas concepções, Einstein tornou-se cada vez mais devoto da causa pacifista, mesmo porque, percebeu, antes de todos, que Hitler estava disposto a entrar em guerra. Quando Hitler tornou-se chanceler da Alemanha em 30 de janeiro de 1933, Einstein compreendeu que a sua situação se tornava insustentável na Alemanha e decidiu que não mais retornaria ao país depois de sua visita aos Estados Unidos. Em março de 1933 ele escreve aos alemães: "Recuso-me a permanecer em um país onde a liberdade política, a tolerância e a igualdade não são garantidas pela lei. Por liberdade política entendo a liberdade de expressar publicamente ou por escrito minha opinião política; e por tolerância, o respeito a toda conviç̧ão individual" (EINSTEIN, 1981, p. 104). E como parte de sua sagacidade, ele escreveu uma carta à Academia das Ciências da Prússia demitindo-se, tirando assim a chance de que o novo governo pudesse fazê-lo. A Academia Prussiana ao invés de assumir o papel crítico que compete à ciência ante qualquer que seja a questão, acovardou-se diante do caso, acusando Einstein de participar da "abominável campanha de imprensa levada a efeito na França e na América". Admite, portanto, a demissão de Einstein, declarando que "não vê nenhum motivo para lastimar a partida de Einstein (apud EINSTEIN, 1981, p. 105). Respondendo às calunias da Academia, Einstein enfatiza sua defesa do pacifismo, reafirma o aniquilamento econômico do povo judeu de origem alemã, acusa a imprensa amordaçada de divulgação tendenciosa de sua demissão e reitera que jamais viverá "num lugar 
onde os cidadãos suportam a desigualdade de direitos perante a lei e onde as ideias e o ensino dependem do controle do Estado" (EINSTEIN, 1981, p. 106).

Como desdobramento de sua demissão da Academia das Ciências da Prússia, que representou uma profunda rejeição ao que se tornara politicamente o Estado alemão em 1933, veio a provocação feita a Einstein pela Academia das Ciências da Baviera. Segundo o seu presidente, a Academia da Baviera que havia elegido Einstein como membro correspondente é igualmente uma Academia alemã e, por isso, solidarizada com a Academia Prussiana. Diante disso, pergunta: "depois do que se passou entre o senhor e a Academia da Prússia, queremos portanto perguntar-lhe como encara suas relações conosco?” (apud EINSTEIN, 1981, p. 110). A resposta de Einstein foi pelo desejo de ter o seu nome riscado da lista de membros correspondentes da Academia da Baviera, enfatizando:

As Academias reconhecem como principal responsabilidade sua a promoção e a salvaguarda da vida científica de um país. Ora, as comunidades culturais alemães, na medida em que posso sabê-lo, aceitaram sem protestos que uma parte não pequena de sábios e de estudantes alemães, bem como de trabalhadores dependentes da instrução acadêmica, tivesse sido privada da possibilidade de trabalho e até mesmo de viver na Alemanha! Com uma Academia que tolera semelhante segregação, mesmo por constrangimento exterior, eu jamais poderei colaborar! (EINSTEIN, 1981, p. 111)

O que se vê em exemplos como esses é um Einstein liberto das amarras nacionalistas, "patrióticas", direitistas e tirânicas, cujos objetivos eram subjugar as liberdades individuais, controlar a educação, coordenar a economia, eliminar os inimigos e promover a eugenia social. Einstein deixa um grande legado que deveria ser copiado por todos os homens de ciência: não basta as grandes produções teóricas e práticas no âmbito da ciência, como não basta o grande número de artigos científicos publicados em veículos de alto fator de impacto, o cientista tem que ter compromisso social. Isso sugere que compete a tal personalidade não ser alienada, descolada do senso de realidade, aquém dos problemas da humanidade e com uma vida devotada somente à prática laboratorial e/ou de gabinete. Se cada um dos grandes nomes da ciência tivesse adotado a postura político-social-pacifista de um Einstein, certamente estaríamos em um mundo melhor. Infelizmente, em virtude da vulnerabilidade da raça humana, temos que conviver com muitas atitudes no campo da ciência, e em outros campos, que representam um total descompromisso com o futuro da humanidade, além de constituir uma completa falta de senso de moralidade. É de se constatar que um Einstein solitário fez muito mais pelo aprimoramento social e humano desse planeta do que muitos daqueles que se conglomeram em torno do ideal da Big Science. A questão que fica, portanto, é: e o que vale Big Science para small minds?

\section{Considerações Finais}

O objetivo do presente artigo era o de apresentar, mesmo que de forma restrita e deficitária, um Albert Einstein diferente daquele que conhecemos pela televisão, pelos livros didáticos e pelas aulas de ciências. Aquele é o Einstein da ciência, cuja genialidade deixou-nos um legado que muito dificilmente será superado. Tínhamos a intenção aqui de apresentar um pouquinho do Einstein cidadão do mundo, cujas preocupações iniciais com a causa da paz transmutaram-se para as preocupações sociais diversas, abrangendo temas relacionados à moral, ao ensino, ao pensamento livre, ao desarmamento, ao serviço militar, às minorias, à economia mundial, aos problemas judaicos, aos trabalhadores intelectuais, à intromissão militar na ciência, ao governo mundial, entre tantos outros mais. Falar sobre esse Einstein das causas da humanidade pressuporia um espaço cujo escopo de um artigo científico seria ínfimo, visto do contingente e da abrangência da sua atuação. Mas, mesmo que pouco, eis que se trata de uma necessidade de nosso tempo. E por que se faz necessário trazer esse Einstein à tona? É justamente o caráter de eterno retorno da história que nos impõe tal necessidade. Vivemos em uma época em que, os fantasmas adormecidos contra os quais Einstein lutou, voltaram a acordar - se é que algum dia eles tiveram, de fato, a dormir! Vemos pelo mundo afora aflorar as 
ideologias nacionalistas de caráter puritano assaltando os direitos sociais das minorias e querendo, mais uma vez, as eliminar; presenciamos o ressurgimento das tiranias, sob roupagem de democracia, ganhar terreno com o discurso de ódio respaldado pelo famigerado "amor à pátria"; testemunhamos o ataque às ciências, à filosofia, às universidades, ao conhecimento, visto da ameaça que estes representam àqueles que gostariam que a humanidade continuasse mergulhada na Idade das Trevas, e se assim continuar, não levará tempo para vermos novamente livros sendo queimados nas praças públicas; observamos países em que a imprensa encontra-se subjugada e amordaçada sem a possibilidade de representar a sua função social de denúncia ante ao estado de injustiças que se instaura, acabando por ser substituída por verdadeiras fábricas de fake news que são propagadas por robôs e financiadas com o dinheiro público por aqueles que querem envenenar e matar os sistemas democráticos; assistimos jovens democracias se diluírem e converterem em ditaduras, sob a liderança ideológica direitista e de caráter fascista, que endeusa os seus líderes transformando-os em personagens mitológicos a serem cultuados pelas massas; enfim, assistimos, por todos os lados, comportamentos chauvinistas onde a opinião exacerbada, tendenciosa e agressiva em favor de uma ideologia, grupo ou país, geralmente se identifica com expressões de rejeição radical aos que lhes são contrários ou diferentes - acompanha-se a isso, o desprezo às minorias, o narcisismo, o autoritarismo e o egocentrismo dos chauvinistas de plantão. Dessa forma, pergunta-se: faz ou não faz sentido que novos Einsteins renasçam das cinzas? Claro que sim! Mas, para que isso aconteça, faz-se necessário que os seus exemplos sejam publicizados para que se possam despertar entre os intelectuais da contemporaneidade (cientistas, filósofos, sociólogos, antropólogos, etc.) o mesmo desejo que o Einstein tinha pelo mundo ordenado e pacífico. Para isso, cremos que dois preceitos da cartilha de Einstein devam ser reproduzidos: primeiro, é preciso que entendamos a conexão da parte com o todo na ordem universal. Entender isso, sugere uma espécie de religiosidade cósmica que nos faz enxergar as conexões e descobrir o nosso lugar nessa engrenagem; segundo, descobrir o nosso lugar nessa engrenagem sugere-nos renunciar à indiferença ante aos problemas do nosso tempo e engajar na luta pela mudança. Parece-nos que só quem atingiu a maturidade religiosa ligada ao cosmo consegue ter uma visão panorâmica do seu lugar no Universo.

\section{Referências}

EINSTEIN, Albert. Como vejo o mundo. Trad. H. P. de Andrade. Rio de Janeiro: Nova Fronteira, 1981.

. Escritos da maturidade: artigos sobre ciência, educação, religião, relações sociais, racismo, ciências sociais e religião. Trad. Maria Luiza X. de A. Borges. Rio de Janeiro: Nova Fronteira, 1994.

. O Perigo Fascista e os meios de o Combater. Trad. Bruno Monteiro. New York Times, 30 abr. 1939. Disponível em: https://www.marxists.org/portugues/einstein/1939/04/30.htm. Acesso em: 15 jun. 2020.

EINSTEIN, Albert et al. Visita de Menachen Begin e objetivos do movimento político discutidos. New York Times, 04 dez. 1948. Disponível em: http://outrasbossas.com.br/OutrasBossas01/index.php?option=com_content\&view=article\&id=99\&catid=24\&Itemid=253. Acesso em: 16 jun. 2020.

ROBINSON, Andrew. Einstein: os 100 anos da Teoria da Relatividade. Trad. Regina Lyra, Marco Mariconi. Rio de Janeiro: Elsevier, 2005. 